\title{
FEW ASPECTS REGARDING BRIBERY AS A SOCIAL AND ECONOMIC THREAT $^{*}$
}

\author{
Alexandru Florin MĂGUREANU, Lecturer $\mathrm{PhD}$. \\ Spiru Haret University, Faculty of Legal and Administrative Sciences, Braşov \\ postdoctoral student, “Acad. Andrei Rădulescu” Legal Research \\ Institute of Romanian Academy \\ Email: magureanu_alexandru_1982@yahoo.com
}

\begin{abstract}
It is a well-known fact that the so called "white collar crimes" now implies a wide variety of offenses (including bribery) that can affect the lives of more individuals than the "classic" crimes. An analysis of corruption necessarily implies an interdisciplinary approach, as it has multiple facets: social, political, economic and juridical. The New Criminal Code of Romania (NCC) has brought a series of important changes, compared to the previous regulation. All forms of corruption involve an abusive use of power (public or private), for a personal gain, occurring regardless of the form of government or historical period.
\end{abstract}

Keywords: bribery, corruption, crime, social and economic costs

JEL Classification: $\mathrm{K}_{00}, \mathrm{~K}_{1}, \mathrm{~K}_{2}, \mathrm{~K}_{3}, \mathrm{~K}_{4}$

\section{General aspects}

Corruption is not a new phenomenon, as its origin dates back to the birth of the state. In Roman law for example, the person that accepts bribe during a trial is treated as a fur manifestus and sanctioned by a quadruple punishment and the attempt to bribe the accuser equate an implicit confession (Cocoş Şt., Măgureanu A. F., 2014, p. 254).

According to a report made by Transparency International for the year 2013, 27 per cent of the interviewed peoples have paid a bribe in the last 12 months when interacting with key public institutions and services, of which the police and the judiciary are seen as the most bribery-prone (http://www.transparency. org/gcb2013/report). Also, the majority of people around the world believe that

* Acknowledgement: This paper has been financially supported within the project entitled "Horizon 2020 - Doctoral and Postdoctoral Studies: Promoting the National Interest through Excellence, Competitiveness and Responsibility in the Field of Romanian Fundamental and Applied Scientific Research", contract number POSDRU/159/1.5/S/140106. This project is co-financed by European Social Fund through Sectoral Operational Programme for Human Resources Development 2007-2013. Investing in people! 
their government is ineffective at fighting corruption and that corruption in their country is getting worse. According to the same source, $76 \%$ of respondents in Romania felt that political parties were corrupt, $68 \%$ that the parliament was corrupt, $49 \%$ that business was corrupt and $50 \%$ that public officials and civil servants were corrupt. In Switzerland, the percentages are as follows: $43 \%$ of the respondents felt that political parties were corrupt, $25 \%$ - the parliament; $36 \%$ business; $23 \%$ public officials and civil servants. In Bulgaria: $76 \%$ - political parties; $71 \%$ - the parliament; $63 \%$ - business; $64 \%$ - public officials and civil servants. In Germany: $65 \%$ - political parties; $48 \%$ - parliament; $61 \%$ - business; $49 \%$ - public officials and civil servants. The statistics above may serve as a clear proof that corruption knows no borders and it is wide spread, including countries that are economically developed. Corruption creates a serious threat to the power structures, the economic reform, business of all kind and to the state of law, to the very foundations of a democracy. The causes that contribute to the proliferation of corruption are numerous: the dissolution of state`s authority, a thick legal frame, legislative incoherence, excessive bureaucracy, inappropriate functioning of public authorities that are responsible for the administration of justice (Boroi A., Gorunescu M., Barbu I. A., 2011, p. 432). Corruption affects all segments of society, including businesses, as it affects markets and competition. Concepts such as ethics, integrity and corruption may apply in different contexts. For example, individuals and organizations alike have standards and moral principles and their behavior may or may not comply with ethical principles. It has become clear today that the role that a corporation (or any other form of business) cannot be reduced to obtaining a profit.

\section{Bribe taking (passive corruption)}

According to the preamble of the Criminal Law Convention on Corruption (signed at Strasbourg in 1999) "corruption threatens the rule of law, democracy and human rights, undermines good governance, fairness and social justice, distorts competition, hinders economic development and endangers the stability of democratic institutions and the moral foundations of society". The criminal codes of the EU member states are making a distinction between active and passive bribery of public officials.

In Romania, the crimes of corruption are also being regulated by special laws (even after the entry into force of the NCC), such the Law nr. 78/2000, which applies to following categories of persons:

a) that are exercising a public office, regardless of the way they were invested in the function that is public or that serves public institutions;

b) that are performing, permanently or temporary, according to the law, a position or an assignment, if they partake in decision taking or if they can influence the decisions, within the public services, autonomous administrations (legal entity whose patrimony consists of assets belonging to the public domain, that are of national or local interest, or that belong to the private property of the state); 
c) that are exercising powers of control, according to the law;

d) that are providing expert assistance to the units stipulated by letters a) and b), to the extent that they are participating to the decision making process and they can influence those decisions;

e) that, regardless of their quality, are performing, controlling or providing expert assistance to the extent that they are participating to the decision making process and they can influence those decisions regarding: operations that are involving the movement of capital, banking operations, currency exchange or credit operations, investment operations in stocks, insurances, mutual investments or regarding bank accounts and those assimilated to them, national or international commercial transactions;

f) that are holding a leadership position in a political party (or any other form of political formation), in a syndicate, employers' organization or non-profit association or foundation;

g) other categories of physical persons, according to the law.

The NCC incriminates deeds of corruption at Title V, Chap. I, articles 289-294 (bribery taking, bribery giving, influence trafficking, buying influence, crimes committed by members of an arbitration tribunal or related to them, crimes committed by foreign officials or related to them).

The special legal object of corruption crimes is represented by the social relations that are forming and developing in relation with the service duties of the officials, which requires an honest attitude, high professional and moral integrity, so as to ensure compliance with the law, the rules of professional ethics, as well as the protection of human rights and legitimate expectations of the citizens.

The incrimination of bribe taking, in art. 289 of the NCC is wider, as it is no longer required for the perpetrator to perform, not perform or delay the completion of an act regarding his attributions or in the purpose of performing an act that is contrary to those attributions (as it was stipulated in the art. 254 of the former Criminal Code). According to the NCC, the constitutive elements of the crime will be met when the active subject performs, does not perform, urges or delays the completion of an act, that is part of his legal attributions or that is related to the completion of a contrary act. Thus, many of the difficulties that existed previously regarding the distinction between bribe taking and receiving illegal benefits (crime that is no longer incriminated separately, as it is absorbed by the crime we are now analysing) have been eliminated.

We must also take into account the fact that, according to art. 7 of the law nr. 78/2000, the crime of bribe taking is considered more serious and punished more severe, if it is committed by one of the following persons:

a) that exercise a function or public dignity;

The function of public dignity is a function occupied by direct mandate, elections organized indirectly or by appointment, according to the law.

b) that have the quality of judge or prosecutor;

c) that have attributions in the criminal prosecution or in the finding or sanctioning offenses; 
d) that is one of the persons stipulated by art. 293 of the NCC, the punishment provided by art. 289 or 291 of the NCC shall be increased by one third.

The crime does not have a material object, as the sums of money, the values or any other benefits acquired, towards which the criminal activity is directly aimed, does not represent a material object, but a product of the crime.

The active subject of the crime is qualified as a public official. It is irrelevant, for the existence of the crime if the active subject receives a remuneration or not, or if he exercises his attributions on a permanent basis or temporarily.

The main passive subject of the crime is represented by the public authority, the public institution or the authority (including legal entities, even if they are not public) were the perpetrator activates. Any physical or juridical person that is affected by the crime can be adjacent passive subject.

The crime may also be committed by inaction, for example, when the active subject does not reject the offer of money or other illegal benefits.

The existence of the crime is not conditioned by the use of the illegal benefits. The constitutive content of the crime will be met even if, for example, the money received is counterfeit, or if they no longer have circulatory value, or even if the money is being given in the form of a loan (High Court of Cassation and Justice, Penal Decision nr. 6560/2004).

The crime can also consist in illegally expediting an act, if the active subject is not one of the categories of persons enumerated by art. 175, paragraph (2) (for example public notaries, as they are legally able to charge supplementary fees, for the completion of an act urgently).

The immediate result of the crime consists in the creation of a dangerous state for the functioning of the institution or authority were the corrupted official works. It is not necessary to produce a determined prejudice.

\section{Bribe giving (active corruption)}

Bribe giving is incriminated by art. 290 of the NCC. The deed consists in promising, offering or giving money or other illegal benefits. The constraint of a person to give bribe removes the criminal nature of the action (New Criminal Code of Romania, art. 290, paragraph (2). It is necessary however for the constraint to be real (even if it is physical or psychical). If the act was not necessary for the person and renouncing at the act would not have had important moral or patrimonial consequences, or if the bribe giver could have found another way (legally) to achieve his desire, the crime will subsist. Similarly, to bribe taking, in the NCC, the crime is no longer conditioned by a specific purpose (to perform, not to perform an act, to delay or to make a contrary act). According to the new regulations, it suffices for the action to be related with fulfilment, failure to fulfil an act, urging or delaying such an act if it is part of the service duties or related to the completion of an act that is contrary to these duties.

Similarly with the crime of bribe taking, the crime we analyse lacks a material object, as the money or other illegal benefits represent the means by which the deed is being perpetrated and not material object. 
Any person that has criminal liability can be active subject of the crime.

It is important to note that, in contrast to the previous Criminal Code, the moment when the bribe is being given is not important. The crime subsists even if the promise or the giving takes place prior to the completion of the act by the public official, but also it takes place following the deed, regardless of the existence of a prior agreement between the bribe giver and the public official. Also it is irrelevant if the act is congruous with the service duties of the official or contrary to those obligations (the crime will subsist even if the official performs his duties, accordingly with his legal obligations and job description, in a fair manner, but accepts money or other illegal benefits in relation with his actions).

The immediate result of the crime is similar with the one of bribe taking.

\section{Conclusions}

According to an estimation the public funds lost to corruption worldwide raises to 1600 billion dollars (http://www.havocscope.com/tag/corruption/). The general cost of corruption is considered to be more than 5\% of global GDP, reaching more than 2600 billion dollars (http://www.oecd.org/cleangovbiz/ 49693613.pdf). We consider however that the real cost of corruption is so much larger that it is impossible to give a proper estimation. We base this affirmation on two undeniable facts:

- a very small percentage of corruption crimes are being reported and investigated by the authorities. This happens on the account that bribery, or taking "the shorter" yet wrong path, can bring huge advantages for both the bribe giver and the bribe taker. Thus, neither of them has an interest in reporting such a deed;

- the cost of corruption consists not only in the loss of money (for example in the case of public contracts) but also in emotional, moral, sociological damages, in the lack of trust in key public institutions, in important corporations, in political representatives or other entities. Such losses are usually impossible to become quantifiable in money.

In order to fight corruption, any juridical entity (including corporations) must primarily take internal measures of preventing it. However undertaking such measures is not an easy task, especially if the market, the general surrounding of that company is not a fair one.

It is unlikely that corruption will ever be completely eradicated. However it can be dramatically reduced, primarily by a proper education, by making peoples realizing the costs and the long term implications of any act of corruption, no matter how small (as none of them are irrelevant). Steps towards reducing corruption can only be taken by an amalgam of measures, including legal, sociological and economic steps. We consider that in order to prevent corruption it must be rendered too expensive for it to be practiced. By "expensive" we do not necessarily refer to more severe legal punishments or actions, but by creating less bureaucratic environment, by encouraging an anti-corruption education and a functional market, so that bribery ceases to be seen as an easier way to obtain an 
act, authorization, to achieve a function, a position, a contract, a preeminent position in a market etc.

We consider that the NCC has taken important steps forwards in the fight against corruption. It is an important improvement the fact that receiving unfair advantages is no longer incriminated distinctly; such a deed can now be considered a crime of bribe taking, according to the art. 289 of the NCC. The article mentioned above has become more comprehensive, as it also includes any form of accepting money or other illegal benefits (tacitly or explicitly), in the benefit of the official or another person.

\section{REFERENCES}

(1) Boroi Alexandru, Gorunescu Mirela, Barbu Ionuţ A. (2011), Dreptul penal al afacerilor (Business Criminal Law), Bucharest: C. H. Beck

(2) Cocoş Ştefan, Măgureanu Alexandru Florin (2014), Instituţii de drept penal roman (Institutions of Roman criminal law), Bucharest: Pro Universitaria, p. 254

(3) Dobrinoiu Vasile, Neagu Norel (2011), Drept penal. Partea specială, Bucharest: Universul Juridic, p. 438

(4) High Court of Cassation and Justice, Penal Decision nr. 6560/2004

(5) New Criminal Code of Romania, art. 290, paragraph (2)

(6) http://www.transparency.org/gcb2013/report

(7) http://www.transparency.org/gcb2013/country?country

(8) http://www.havocscope.com/tag/corruption/

(9) http://www.oecd.org/cleangovbiz/49693613.pdf 